\title{
ПОДХОДЫ К ВЫБОРУ СОНОСЕНСИБИЛИЗАТОРОВ ДЛЯ МЕТОДА СОНОДИНАМИЧЕСКОЙ ТЕРАПИИ ОНКОЛОГИЧЕСКИХ ЗАБОЛЕВАНИЙ
}

\author{
А.В. Гопин ${ }^{1}$, Н.В. Андронова², Е.М. Трещалина², А.В. Саранцев', \\ А.Л. Николаев ${ }^{1}$ \\ ${ }^{1}$ Химический факультет, Московский государственный университет имени \\ М.В.Ломоносова, 119991, Россия, Москва, Ленинские горы, д. 1, стр. 10. \\ ФГБУ «НМИЦ онкологии им. Н.Н. Блохина» Минздрава России, \\ 115478, Россия, Москва, Каширское шоссе 24.
}

В медицине для терапии онкологических заболеваний применяются различные физические факторы, в частности ультразвук. Одним из перспективных ультразвуковых методов является сонодинамическая терапия. В ее основе лежит воздействие на опухоль ультразвука средней интенсивности в присутствии предварительно введенных в нее веществ - соносенсибилизаторов. Основным разрушающим фактором полагают активные формы кислорода, возникающие при воздействии на среду, содержащую сенсибилизатор и молекулярный кислород, ультразвука. Было оценено соносенсибилизирующее действие производных фталоцианинов - октанатриевые соли октакарбоксифталоцианина кобальта и октакарбоксифталоцианина цинка. Нами показано, что в их присутствии генерация активных форм кислорода увеличивается. Совместное действие ультразвука и соносенсибилизаторов на опухоли экспериментальных животных приводит к существенному торможению их роста - до 2-3 раз по сравнению с контролем. Другим фактором может быть уменьшение прочности мембран клеток или кавитационной прочности среды при введении соносенсибилизатора, что может привести к деструкции опухолевой ткани кавитационными событиями. Это может происходить при введении в опухоль различных наночастиц. Так, нами показано соносенсибилизирующе действие наночастиц гидроксиапатита, связанного с альбумином, который интенсивно метаболизируется опухолью, обеспечивая транспорт. В оптимальных условиях противоопухолевый эффект комбинированного действия ультразвука и наночастиц гидроксиапатита превышает ультразвуковой в 2-3 раза и сопоставим со стандартной химиотерапевтической схемой. Не исключено подобное действие и в случае производных фталоцианинов, которые в физико-химических условиях опухолевой ткани способны образовывать твердую фазу кислых форм или кальциевых солей.

Таким образом, при выборе соносенсибилизаторов следует руководствоваться не только данными о генерации активных форм кислорода, но и о способности формировать наночастицы твердой фазы в условиях опухоли. 